\title{
ANALISIS PENGARUH KEADAAN EKONOMI MAKRO TERHADAP INVESTASI ASURANSI JIWA SYARIAH DI INDONESIA TAHUN 2010 - 2019
}

\author{
Khalish Khairina \\ Fakultas Ekonomi dan Bisnis Islam IAIN Lhokseumawe, \\ email: khaliskhairina@iainlhokseumawe.ac.id
}

\begin{abstract}
This study aims to analyze the effect of Inflation, Exchange Rate, BI Interest Rate, Indonesia Composite Index on Sharia Insurance Life in Indonesia. Data used is time series data for 10 years (2010-2019) and analyzed by using Eviews 10. This research using quantitative descriptive method, and to analyze the effect of independent variables toward dependent variables using Ordinary Least Square technique. The result of $t$ - test shows Inflation, Exchange Rate, Indonesia Composite Index have significant influence to Sharia Life Insurance Investment in Indonesia that $t$-test $<0,05$ and Interest Rate doesn't influence to Sharia Life Insurance Investment in Indonesia with $t$ - test $>0,05$. However, independent variables has a significant influence with the result of $\mathrm{F}$ test 0,000002 $<0,05$ and Adjusted R-Squared test shows that $99,41 \%$ of Sharia Life Insurance Investment in Indonesia is influenced by independent variables in this research
\end{abstract}

Key words : Inflation, Exchange Rate, Interest Rate, Indonesia Composite Index , Sharia Insurance Life Investment 


\begin{abstract}
Abstrak
Penelitian ini bertujuan untuk menganalisis pengaruh dari variabel Inflasi, Nilai Tukar (Kurs), Suku Bunga Acuan, dan Indeks Harga Saham Gabungan (IHSG) terhadap Investasi Asuransi Jiwa Syariah di Indonesia. Data yang digunakan merupakan data time series dalam kurun waktu 10 tahun (2010 - 2019) yang diolah menggunakan Eviews 10. Penelitian ini menggunakan metode penelitian deskriptif kuantitatif dan untuk melihat pengaruh variabel bebas terhadap variabel terikat menggunakan teknik Regresi Sederhana (Ordinary Least Square). Hasil dari uji t menyatakan bahwa Inflasi, Kurs, serta IHSG memiliki pengaruh yang signifikan terhadap hasil investasi asuransi jiwa syariah di Indonesia, ditandai dengan hasil t - test $<0,05$. Sedangkan variabel Suku Bunga Acuan tidak memberikan pengaruh terhadap hasil investasi asuransi jiwa syariah di Indonesia ditandai dengan hasil t-test > 0,05. Meskipun demikian, Inflasi, Nilai Tukar, Suku Bunga Acuan, dan IHSG secara bersama - sama berpengaruh terhadap hasil investasi asuransi jiwa syariah di Indonesia dengan nilai uji F 0,000002 <0,05. Melihat nilai Adjusted R-Squared, maka 99,41\% investasi asuransi jiwa syariah di Indonesia dipengaruhi oleh variabel bebas dalam penelitian ini.
\end{abstract}

Kata Kunci : Inflasi, Kurs, Suku Bunga Acuan, IHSG, Investasi Asuransi Jiwa Syariah 


\section{PENDAHULUAN}

Indonesia merupakan negara dengan Islam sebagai agama yang paling banyak dianut oleh penduduknya. Ajaran Islam mengajarkan penganutnya untuk memperhatikan kehalalan dalam setiap sendi kehidupan, menyebabkan Indonesia menjadi negara yang berpotensi sangat besar sebagai pusat pengembangan kegiatan ekonomi syariah dan keuangan syariah. Melihat peluang itu, pemerintah Indonesia melalui Otoritas Jasa Keuangan mengelola Industri Keuangan Non Bank (IKNB) Syariah terdiri atas Perasuransian Syariah (Perusahaan Asuransi Jiwa Syariah, perusahaan Asuransi Umum Syariah, dan Perusahaan Reasuransi Syariah), Perusahaan Pembiayaan Syariah, Perusahaan Modal Ventura Syariah, Perusahaan Pembiayaan Infrastruktur Syariah, Dana Pensiun Syariah, Lembaga Jasa Keuangan Syariah Khusus (Perusahaan Penjaminan Syariah, Perusahaan Pergadaian Syariah, Lembaga Pembiayaan Ekspor Indonesia (LPEI) (unit syariah), dan Perusahaan Pembiayaan Sekunder Perumahan (unit syariah), dan Lembaga Keuangan Mikro Syariah.

Pada tahun 2018 tercatat lebih dari satu juta orang yang berangkat umrah dari Indonesia, fenomena ini mendorong pemerintah pusat mengeluarkan banyak keputusan terkait dengan keuangan syariah diantaranya adalah keputusan yang dikeluarkan oleh Kementerian Agama melalui Surat Keputusan Direktur Jenderal Penyelenggaraan Haji dan Umrah Nomor 336 tahun 2018. Keputusan ini mendorong setiap jamah Haji dan Umrah untuk menggunakan program asuransi jiwa syariah. Peraturan ini menyebutkan tentang asuransi perjalanan sebagai asuransi jemaah umrah berupa asuransi jiwa, kesehatan, dan kecelakaan. Seluruhnya harus merupakan asuransi berbasis syariah. Jamaah umrah wajib mendapatkan asuransi jiwa, kesehatan, kecelakaan, dan cover nilai manfaat lainnya. Regulasi ini memberikan kepastian perlindungan dan hak - hak jamaah. Hal ini tentunya akan menyebabkan bertambahnya jumlah nasabah asuransi jiwa syariah dan perusahaan asuransi jiwa syariah di Indonesia.

Jenis produk Asuransi Jiwa Syariah terdiri dari beberapa produk yaitu asuransi jiwa berjangka, asuransi dwiguna, asuransi seumur hidup, asuransi kecelakaan diri, asuransi kesehatan (OJK, 2018). Pada tahun 2019 perusahaan asuransi jiwa syariah di Indonesia berjumlah 23 perusahaan, lebih banyak dibandingkan pada tahun 2016 yang hanya berjumlah 21 perusahaan. diperkirakan penduduk Indonesia dengan mayoritas muslim sebagai agamanya sudah banyak yang mengalihkan investasi asuransi umum mereka ke asuransi jiwa dengan prinsip syariah. Hal ini terlihat, pada tahun 2019 hasil investasi asuransi jiwa syariah berjumlah Rp 34,327 miliar rupiah, meningkat sebesar 7,67\% dibandingkan pada tahun 2018 yang hanya sebesar Rp. 31,882 miliar. 
Tabel 1. Perkembangan Market Share IKNB Syariah Tahun 2016 - 2018

\begin{tabular}{lllll}
\hline Jenis Perasuransian & \multicolumn{4}{l}{ Market Share } \\
\cline { 2 - 5 } & 2015 & 2016 & 2017 & 2018 \\
Asuransi Jiwa Syariah & $5,98 \%$ & $6,68 \%$ & $6,22 \%$ & $6,21 \%$ \\
Asuransi Reasuransi Syariah & $5,80 \&$ & $6,52 \%$ & $6,18 \%$ & $8,11 \%$ \\
\hline
\end{tabular}

Sumber : OJK, data diolah

Meskipun demikian, market share yang dicapai oleh investasi asuransi jiwa syariah mengalami penurunan pada tahun 2018 yaitu $6,21 \%$ yang sebelumnya pada tahun 2017 dan 2016 sebesar 6,22\% dan 6,86\% seperti yang terlihat pada tabel 1. Apabila dibandingkan dengan hasil investasi asuransi jiwa konvensional yang mampu meraup investasi sebesar Rp. 488,183 miliar pada tahun maka dapat disimpulkan industri asuransi jiwa masih didominasi oleh asuransi jiwa konvensional. Padahal dengan melihat potensi penduduk Indonesia mayoritas muslim, dapat menjadi peluang bagi perusahaan asuransi jiwa syariah untuk menaikkan market share. Ditambag lagi, di dalam asuransi jiwa syariah, dana yang diberikan nasabah merupakan dana tabarru yang artinya resiko ditanggung bersama dan dikelola secara islami. Dalam asuransi jiwa syariah, investasi dikelola secara islami yang tentunya cara berinvestasi adalah dengan membeli instrumen investasi yang terbebas dari penipuan, perjudian, maupun barang haram, begitu juga dengan membeli saham yang berlabel syariah. (Anshory, 2007). Keadaan perekonomian makro yang baik akan mempengaruhi investor untuk berinvestasi. Secara teori, tingkat investasi dipengaruhi oleh keadaan perekonomian yaitu tingkat suku bunga, produk nasional bruto, perubahan teknologi, serta tingkat pengembalian keuntungan (Karim, 2006).

Peraturan Menteri Keuangan Nomor 11/PMK.010/2011 tentang Kesehatan Keuangan Usaha Asuransi dan Usaha Reasuransi dengan Prinsip Syariah, menyatakan kekayaan yang diperkenankan dalam bentuk investasi adalah : deposito pada Bank, saham syariah, sukuk atau obligasi syariah, Surat Berharga Syariah Negara, Surat berharga syariah yang diterbitkan oleh Bank Indonesia, surat berharga syariah yang diterbitkan oleh negara selain negara Republik Indonesia, surat berharga syariah yang diterbitkan oleh lembaga multinasional yang Negara Republik Indonesia menjadi salah satu anggota atau pemegang sahamnya, pembiayaan melalui mekanisme kerjasama dengan pihak lain dalam bentuk pembelian pembiayaan (refinancing) syariah serta emas murni (OJK, 2020)

Berdasarkan peraturan tersebut, laporan kinerja perusahaan akan sangat mempengaruhi terhadap proses pemilihan investasi. Investor tentu akan mempertimbangkan untuk berinvestasi di perusahaan asuransi yang memberikan keuntungan 
yang besar dengan tingkat kerugian yang rendah. Jumlah investasi pada teorinya dipengaruhi oleh kinerja ataupun kondisi perekonomian makro yang baik, seperti inflasi yang terkendali, Kurs, BI - 7 Days Repo Rate, Indeks Harga Saham Gabungan, tingkat pajak yang rendah. Fluktuasi IHSG berpengaruh secara positif dan signifikan terhadap return pada produk unitlink syariah berbasis saham di perusahaan Asuransi Jiwa pada tahun 2017. Perubahan yang terjadi pada nilai IHSG mempengaruhi return pada unitlink syariah berbasis saham disebabkan investasi saham dilakukan oleh Perusahaan Asuransi Jiwa berada (Restiana, 2017).

Menurut Metwally dalam Karim (2006) investasi dalam perekonomian Islam sangat berbeda dengan ekonomi konvensional. Ada tiga pilihan bagi muslim yang ingin menginvestasikan dananya yaitu memegang dananya dalam bentuk uang tunai, memegang dananya dalam bentuk aset - aset yang tidak menghasilkan pendapatan atau menginvestasikan dananya untuk menambah modal negara. Pilihan terakhir merupakan pilihan yang dianjurkan oleh Islam. Menurut Chen, Roll dan Ross (2004), faktor - faktor yang mempengaruhi investasi dalam suatu perusahaan adalah, tingkat inflasi, nilai tukar mata uang, dan keadaan perekonomian negara.

Inflasi merupakan kenaikan harga barang secara umum dan terus - menerus selama periode tertentu, (Karim, 2006). Oleh karena itu, para ekonom modern mendefinisikan inflasi sebagai suatu kenaikan menyeluruh dari jumlah uang yang harus dibayarkan terhadap barang - barang dan/komoditas dan jasa. Naik turunnya kurs Rupiah terhadap mata uang asing tentu akan memberikan pengaruh terhadap investasi dalam negeri. Penelitian yang dilakukan oleh FD Zein (2015) menunjukkan inflasi, nilai tukar dan Produk Domestik bruto secara simultan berpengaruh terhadap hasil investasi perusahaan asuransi jiwa syariah di Indonesia. Selanjutnya, tingkat suku bunga acuan juga mempengaruhi hasil investasi, hal ini dikemukakan oleh Irmawati (2017) setiap kenaikan 1\% BI Rate, maka akan mengurangi hasil investasi perusahaan asuransi jiwa syariah di Indonesia

\section{LANDASAN TEORITIS}

\section{Investasi Dalam Islam}

Islam mengajarkan pemeluknya untuk menabung dan berinvestasi. Islam menganjurkan untuk tidak menghabiskan semua pendapatan, namun kita dianjurkan untuk mengelola dan mengembangkan. Hal ini dianjurkan pada ayat Alqu'an surat Yusuf ayat 46 - 50 yang artinya sebagai berikut :

12:46. (Setelah pelayan itu berjumpa dengan Yusuf, dia berseru): "Yusuf, hai orang yang amat dipercaya, terangkanlah kepada kami tentang tujuh ekor 
sapi betina yang gemuk-gemuk yang dimakan oleh tujuh ekor sapi betina yang kurus-kurus dan tujuh bulir (gandum) yang hijau dan (tujuh) lainnya yang kering agar aku kembali kepada orang-orang itu, agar mereka mengetahuinya."

12:47. Yusuf berkata: "Supaya kamu bertanam tujuh tahun (lamanya) sebagaimana biasa; maka apa yang kamu tuai hendaklah kamu biarkan dibulirnya kecuali sedikit untuk kamu makan.

12:48. Kemudian sesudah itu akan datang tujuh tahun yang amat sulit, yang menghabiskan apa yang kamu simpan untuk menghadapinya (tahun sulit), kecuali sedikit dari (bibit gandum) yang kamu simpan.

12:49. Kemudian setelah itu akan datang tahun yang padanya manusia diberi hujan (dengan cukup) dan di masa itu mereka memeras anggur." (QS Yusuf 12:46-49.)

Kisah Nabi Yusuf As di atas mengajarkan umat Islam untuk tidak menghabiskan semua kekayaan yang ia dapat, tetapi juga ditabung atau dikelola untuk menghadapi masa yang akan datang. Berinvestasi pada masa sekarang dapat berupa menyimpan emas, membeli rumah, membeli saham, ataupun menggunakan asuransi. Bentuk bentuk spekulasi seperti perlombaan, permainan kartu, aktivitas perjudian, dilarang dalam ajaran Islam. Menurut Metwally dalam Karim (2006;298), la meniadakan suku bunga pinjaman dengan variable expected rate, yaitu tingkat suku bunga yang ditentukan oleh pasar kredit dengan asumsi terdapat denda untuk penimbunan asset -aset yang tidak termanfaatkan, dilarangnya segala bentuk spekulasi dan tindakan perjudian, serta tingkat suku bunga pada semua jenis dana pinjaman adalah nol. Sehingga, fungsi investasi dalam Islam adalah sebagai berikut:

$$
I=f(r, \mu)
$$

Keterangan :

$\mathrm{I}=$ permintaan investasi

$r \quad$ = tingkat keuntungan yang diharapkan

$\mu=$ pengeluaran lain - lain zakat atas asset yang tidak atau kurang produktif

Menurut Metwally dalam Karim (2006;299) tingkat keuntungan yang diharapkan dan pengeluaran lain - lain zakat atas asset yang tidak atau kurang produktif merupakan penyebab kecilnya investasi dalam perekonomian Islam. Prinsip asuransi jiwa syariah berbeda dengan asuransi jiwa konvensional, dana nasabah disebut sebagai dana Tabarru' yang berarti kontribusi seluruh nasabah yang akan diberikan sebagai hibah pada nasabah lain yang menghadapi resiko (risk sharing antar nasabah). Selanjutnya dana nasabah akan digunakan untuk dua tujuan yaitu dikumpulkan un- 
tuk dana tabarru' dan juga akad tijarah, perusahaan asuransi akan menginvestasikan dana nasabah. Tentunya perusahaan asuransi akan menginvestasikan dana nasabah pada instrument investasi yang berbasis syariah juga, yaitu instrument investasi yang terbebas dari Gharar (ketidakjelasan), riba, atau Masyir (perjudian).

\section{Inflasi}

Fenomena moneter yang sering terjadi di manapun adalah Inflasi. Menurut Mankiw (2007; 75) inflasi merupakan perubahan persentase dalam seluruh tingkat harga, sangat bervariasi sepanjang waktu dan antar negara. Menurutnya, inflasi merupakan kenaikan dalam tingkat harga rata - rata dan harga merupakan uang yang harus ditukarkan untuk mendapatkan barang atau jasa. Inflasi dapat diukur dengan melihat tingkat inflasi (rate of inflation) dengan mengukur rata - rata harga yang dibeli oleh konsumen. Inflasi memiliki pengaruh positif dan negatif terhadap perekonomian. Indikator yang digunakan dalam mengukur tingkat inflasi adalah Indeks Harga Konsumen (IHK). Perubahan IHK dari waktu ke waktu menunjukkan pergerakan harga dari paket barang dan jasa yang dikonsumsi masyarakat. Penentuan barang dan jasa dalam keranjang IHK dilakukan atas dasar Survei Biaya Hidup (SBH) yang dilaksanakan oleh Badan Pusat Statistik (BPS). Kemudian, BPS akan memonitor perkembangan harga dari barang dan jasa tersebut secara bulanan di beberapa kota, di pasar tradisional dan modern terhadap beberapa jenis barang/jasa di setiap kota (Bank Indonesia, 2019). Indikator inflasi lainnya berdasarkan international best practice antara lain: Indeks Harga Perdagangan Besar (IHPB), Indeks Harga Produsen (IHP), Deflator Produk Domestik Bruto (PDB), Indeks Harga Aset. Inflasi memiliki akibat yang positif dan negative, inflasi tentu dapat memicu para produsen untuk memproduksi barang lebih banyak dikarenakan mengharapkan keuntungan yang besar. Sedangkan inflasi juga dapat berdampak negatif seperti menurunnya daya beli masyarakat, memburuknya distribusi pendapatan, dan mengganggu stabilitas ekonomi, serta mempengaruhi penurunan pendapatan perusahaan.

Apabila dikaitkan dengan perusahaan asuransi jiwa syariah, inflasi yang tinggi tentu akan menurunkan pendapatan perusahaan karena akan mengganggu pengelolaan dana tabarru. Kondisi ketika beban pengelolaan asuransi lebih besar daripada pendapatan asuransi menandakan turunnya pendapatan perusahaan. Hal ini tentu menurunkan kepercayaan peserta asuransi dikarenakan bagi hasil yang mereka terima lebih sedikit. Penarikan asuransi ini akan berdampak terhadap turunnya investasi asuransi jiwa syariah disebabkan berkurangnya peserta asuransi. 


\section{Kurs (Nilai Tukar)}

Nilai tukar atau kurs merupakan nilai tukar mata uang terhadap pembayaran saat kini atau di kemudian hari, antara dua mata uang masing-masing negara atau wilayah. Sukirno (2002;397) menyatakan bahwa nilai tukar menunjukkan harga atau nilai mata uang sesuatu negara dinyatakan dalam nilai mata uang negara lain. Alhasymi (2010:3) menyatakan penurunan tingkat nilai tukar rupiah dalam jangka pendek akan megurangi penyerapan investasi domestik, sedangkan nilai tukar yang menguat akan menyebabkan kenaikan tingkat harga - harga secara umum dan selanjutnya menurunkan permintaan masyarakat, sehingga perusahaan akan menurunkan alokasi modal pada investasi. Nilai tukar menggambarkan banyaknya satuan mata uang yang didapat (dibeli ataupun ditukar) dengan satuan uang mata uang lainnya. Nilai tukar dapat memengaruhi penanaman modal, efek yang terjadi bergantung dari tujuan investor dalam menanamkan modalnya. Dalam penelitian yang dilakukan Meita Sari dan Kajeng Baskara (2018) menunjukkan inflasi memiliki pengaruh yang signifikan terhadap investasi asing langsung di Indonesia.

\section{Suku Bunga Acuan}

Suku bunga acuan merupakan adalah kebijakan nilai suku bunga yang ditetapkan oleh Bank Indonesia dengan kebijakan moneter yang akan diterapkan pada masyarakat seluruh Indonesia. Suku bunga kebijakan ini mencerminkan sikap atau stance kebijakan moneter yang ditetapkan oleh bank Indonesia dan diumumkan kepada publik (Bank Indonesia, 2019).

Untuk menguatkan sistem operasi moneter maka Bank Indonesia mengimplementasikan suku bunga acuan atau suku bunga kebijakan baru yaitu BI 7-Day (Reverse) Repo Rate, yang berlaku efektif sejak 19 Agustus 2016, menggantikan BI Rate. Hal ini dilakukan untuk memperkuat efektivitas kebijakan agar mencapai sasaran inflasi yang ditetapkan karena BI 7 - Days Repo Rate dinilai cepat dalam memengaruhi pasar uang, perbankan dan sektor riil.sifatnya transaksional atau diperdagangkan di pasar, dan mendorong pendalaman pasar keuangan.

Dengan berlakunya suku bunga acuan baru maka diharapkan ada 3 dampak yang akan terjadi. Pertama, menguatnya sinyal kebijakan moneter dengan suku bunga (Reverse) Repo Rate 7 hari sebagai acuan utama di pasar keuangan. Kedua, meningkatnya efektivitas transmisi kebijakan moneter melalui pengaruhnya pada pergerakan suku bunga pasar uang dan suku bunga perbankan. Ketiga, terbentuknya pasar keuangan yang lebih dalam, khususnya transaksi dan pembentukan struktur suku bunga di pasar uang antarbank.

Fungsi BI 7-Days Repo Rate adalah sebagai bahan pertimbangan untuk memi- 
lih instrumen investasi agar instrument yang diperoleh mendapatkan pengembalian yang tinggi dan resiko yang diterima kecil. BI 7-Days Repo Rate diumumkan oleh Dewan Gubernur Bank Indonesia setiap Rapat Dewan Gubernur bulanan dan diimplementasikanpada operasi moneter yang dilakukan Bank Indonesia melalui pengelolaan likuiditas di pasar uang untuk mencapai sasaran operasional kebijakan moneter. Bank Indonesia akan menaikkan BI 7-Days Repo Rate apabila inflasi di masa yang akan datang diprediksi lebih besar dari yang telah ditetapkan, sebaliknya Bank Indonesia akan menurunkan BI 7-Days Repo Rate apabila inflasi di masa yang akan datang diprediksi lebih kecil daripada yang ditetapkan. Tingkat suku bunga acuan sangat mempengaruhi hasil investasi jiwa syariah di Indonesia, kenaikan BI Rate/ BI- 7 Days sebesar 1\% akan menurunkan jumlah investasi (Irmawati, 2017)

\section{Indeks Harga Saham Gabungan (IHSG)}

Indeks harga adalah angka yang digunakan untuk membandingkan suatu peristiwa dibandingkan dengan peristiwa lainnya. Saham adalah instrumen pasar modal yang paling banyak diminati oleh investor. Indeks Harga Saham Gabungan menunjukkan pergerakan harga saham secara umum, yang tercatat di dalam bursa efek untuk mengukur perubahan harga saham (Pasaribu \& Kowanda, 2014). IHSG atau JCI (Jakarta Composite Index) diperkenalkan pertama kali tanggal 1 April 1993 sebagai indikator pergerakan harga saham yang tercatat di bursa, baik saham biasa maupun saham preferen (IDX, 2018). IHSG menggunakan perusahaan-perusahaan yang tercatat sebagai induk komponen dalam perhitungan angka Indeks. Bursa Efek Indonesia memiliki wewenang khusus dalam mengganti satu atau lebih perusahaan yang tercatat sebagai ilustrasi kondisi pasar dari sisi perhitungan. Indeks harga saham gabungan (IHSG) merupakan wadah bagi perusahaan-perusahaan yang membuka kepemilikan sahamnya terhadap publik melalui mekanisme Initial Public Offering (IPO). Sehingga IHSG adalah dokumentasi pergerakan harga saham baik ketika mengalami penurunan ataupun mengalami peningkatan. Harga saham ini dapat dilihat di Bursa Efek Indonesia (BEI). Pada kuartal I tahun 2019, indeks harga saham gabungan yang menguat membawa perbaikan terhadap investasi asuransi di Indonesia. Direktur Eksekutif Asosiasi Asuransi Jiwa Indonesia (AAJ) Togar Pasaribu mengatakan, peningkatan hasil investasi akan mempengaruhi tingkat kesehatan keuangan perusahaan. Jika kondisi keuangan perusahaan sehat, maka kepercayaan masyarakat terhadap perusahaan asuransi naik hingga akhirnya masyarakat mau membeli produk asuransi.

Berdasarkan uraian di atas maka akan diteliti tentang pengaruh Inflasi, Kurs, Suku Bunga Acuan dan Indeks Harga Saham Gabungan (IHSG) terhadap investasi asuransi jiwa syariah di Indonesia.

Berikut merupakan kerangka berpikir untuk menjelaskan hubungan antara vari- 
abel bebas dengan variabel terikat.

Gambar 1. Kerangka Berpikir

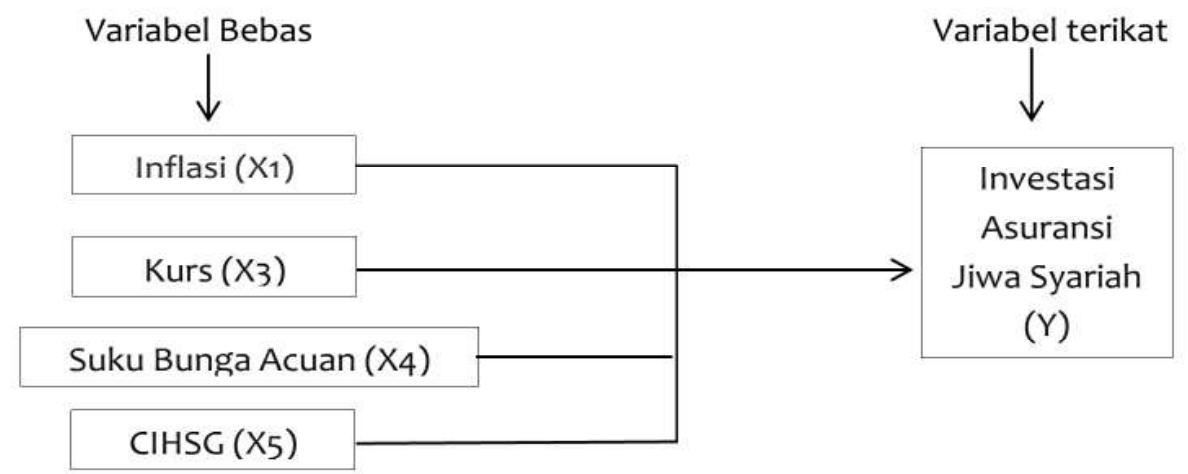

\section{METODE PENELITIAN}

Penelitian ini dilakukan di Indonesia dan merupakan penelitian deksriptif kuantitatif yang meneliti tentang investasi asuransi jiwa syariah di Indonesia menggunakan data time series (data berkala) atas dasar harga konstan 2010 selama 10 tahun (2010 - 2019). Data yang diperoleh merupakan data sekunder yang didapat dari Bank Indonesia untuk data Inflasi, Kurs, dan Suku Bunga Acuan, Bursa Efek Indonesia menyediakan data Indeks Harga Saham Gabungan, serta Otoritas Jasa Keuangan untuk data Investasi Asuransi Jiwa Syariah di Indonesia.

Data di atas dianalisis dengan metode Ordinary Least Square (OLS) dengan taraf error $5 \%$ dan keyakinan 95\%. Data diolah dengan menggunakan aplikasi pengolah data Eviews 10 untuk melihat uji asumsi klasik, yang terdiri dari uji normalitas yang bertujuan untuk mengetahui data berdistribusi normal, uji multikolinieritas yang dilakukan untuk mengetahui uji yang dilakukan untuk memastikan apakah di dalam sebuah model regresi ada interkorelasi atau kolinearitas antar variabel bebas, serta terakhir adalah uji autokorelasi yang bertujuan untuk mengetahui korelasi variabel yang ada di dalam model prediksi dengan perubahan waktu. Uji asumsi klasik ini dilakukan untuk mengetahui apakah model regresi yang diperoleh dapat menghasilkan estimator yang baik. Setelah uji asumsi klasik dilakukan, maka selanjutnya dilakukan uji t, uji f, dan analisis koefesien determinan. Uji t digunakan untuk melihat secara parsial pengaruh variabel bebas terhadap variabel terikat, uji f digunakan untuk mengetahui seberapa besar variabel bebas mempengaruhi atau tidak terhadap variabel terikat, dan analisis koefesien determinan digunakan untuk mengetahui seberapa besar persentase variabel dalam variabel terikat pada model dapat diterangkan oleh variabel bebasnya.

Dalam penelitian ini yang menjadi variabel bebas adalah Inflasi, Nilai Tukar, Suku Bunga Acuan, Indeks Harga Saham Gabungan, sedangkan yang menjadi variabel teri- 
kat adalah Investasi Asuransi Jiwa Syariah di Indonesia. Bentuk persamaan untuk penelitian ini dapat dirumuskan sebagai berikut ini:

$$
Y=\beta_{0}+\beta_{1} I N F+\beta_{2} K U R S+\beta_{3} S B A+\beta_{4} I H S G+\varepsilon
$$

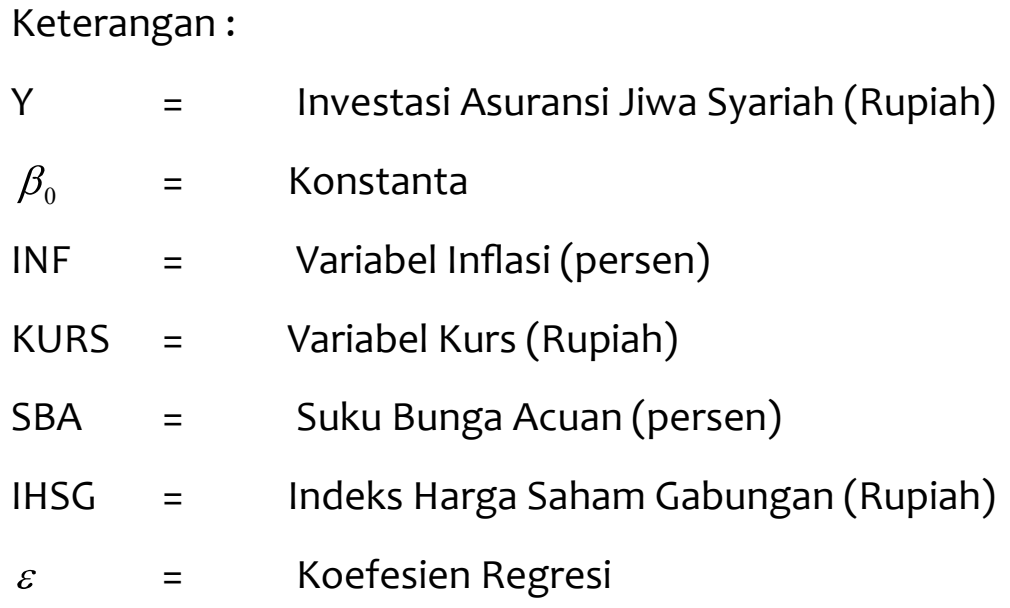

\section{HASIL DAN PEMBAHASAN}

Sebelum dilakukan uji hipotesis, maka data diuji dengan asumsi klasik yaitu pengujian normalitas data. Dalam pengujian normalitas data pada gambar 1, maka dapat diketahui bahwa data yang akan diuji berdistribusi normal dengan nilai probabilitas Jarque Bera (JB) sebesar 1,61 6695 lebih besar dari taraf signifikan 5\%.

\section{Gambar 2. Hasil Uji Normalitas}

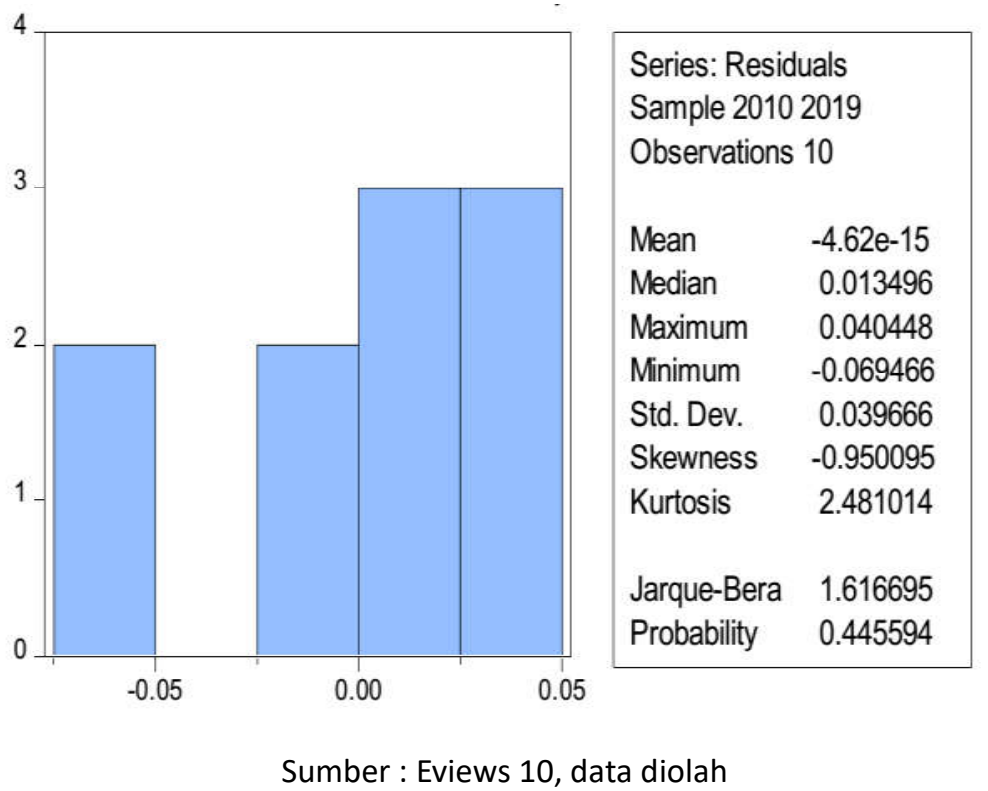

Kemudian, untuk mengetahui data terbebas dari asumsi multikolineritas adalah dengan melihat nilai Variance Inflation Factor (VIF) pada tabel 2, data terbebas dari multikolinieritas apabila VIF $<10$. Melihat hasil centered VIF variabel bebas $<10$ pada 
tabel 2, maka dapat disimpulkan bahwa keempat variabel bebas (inflasi, kurs, suku bunga acuan, dan IHSG) tidak mengandung masalah multikolinieritas.

Tabel 2. Hasil Uji Multikolinieritas

Variance Inflation Factors

Date: 02/20/20 Time: 23:46

Sample: 20102019

Included observations: 10

\begin{tabular}{llll}
\hline \hline Variable & Coefficient Variance & Uncentered VIF & Centered VIF \\
\hline \hline INFLASI & 0.003886 & 136.9930 & 2.280254 \\
KURS & 0.064632 & 20157.96 & 6.433815 \\
SBA & 0.025709 & 723.0518 & 3.449470 \\
IHSG & 0.058194 & 14853.89 & 7.703240 \\
C & 1.206229 & 4259.071 & NA \\
\hline \hline
\end{tabular}

Sumber : Eviews 10, data diolah

Data selanjutnya akan diuji dengan uji Durbin Watson ataupun uji Langrange Multiplier (LM) Test untuk mengetahui data terbebas dari autokorelasi. Hasil nilai probabilitas uji LM test sebesar 0,4517 dimana nilai tersebut lebih besar dari taraf signifikansi $5 \%$ yang berarti tidak terdapat autokorelasi pada persamaan ini. Ketika data terbebas dari asumsi klasik maka langkah selanjutnya adalah pembuktian hipotesis menggunakan uji t yang digunakan untuk menguji koefesien regresi secara parsial dari variabel bebasnya dengan membandingkan nilai t-hitung dengan nilai t-tabel. Berikut hasil output regresi Inflasi, Kurs, Suku Bunga Acuan, dan Indeks Harga Saham Gabungan (IHSG):

Tabel 3. Output Hasil Regresi Inflasi, Kurs, SBA, dan IHSG

Dependent Variable: INVESTASI ASURANSI JIWA

Method: Least Squares

Date: 02/20/20 Time: 23:40

Sample: 20102019

Included observations: 10

\begin{tabular}{lllll}
\hline \hline Variable & Coefficient & Std. Error & t-Statistic & Prob. \\
\hline \hline INFLASI & -0.182136 & 0.062342 & -2.921571 & 0.0330 \\
KURS & 2.194935 & 0.254228 & 8.633739 & 0.0003 \\
SBA & -0.10616 & 0.160341 & -0.662085 & 0.5372 \\
IHSG & 1.375178 & 0.241234 & 5.700608 & 0.0023 \\
C & -23.52782 & 1.098285 & -21.42234 & 0 \\
\hline R-squared & 0.996746 & Mean dependent var & 9.656748 \\
Adjusted R-squared & 0.994143 & S.D. dependent var & 0.695403 \\
S.E. of regression & 0.053218 & Akaike info criterion & -2.721992 \\
Sum squared resid & 0.014161 & Schwarz criterion & -2.5707 \\
Log likelihood & 18.60996 & Hannan-Quinn criter. & -2.88796 \\
F-statistic & 382.9358 & Durbin-Watson stat & 1.818729 \\
Prob(F-statistic) & 0.000002 & & & \\
\hline \hline
\end{tabular}

Sumber : Eviews 10, data diolah 
Selanjutnya adalah menguji hipotesis dengan uji t, melihat hasil regresi pada tabel 3 maka dapat disimpulkan bahwa:

1. Nilai probabilitas inflasi sebesar 0,0330 lebih kecil dari taraf signifikan 0,05 maka dapat disimpulkan bahwa terdapat pengaruh dari variabel inflasi terhadap hasil investasi asuransi jiwa syariah di Indonesia dengan slope negatif pada koefesiannya.

2. Nilai probabilitas kurs sebesar 0,0003 lebih kecil dari 0,05 maka dapat disimpulkan bahwa variabel nilai tukar memiliki pengaruh terhadap hasil investasi asuransi jiwa syariah di Indonesia dengan slope positif pada koefesiennya

3. Nilai probabilitas suku bunga acuan sebesar 0,5372 lebih besar dari 0,05 maka dapat disimpulkan bahwa tingkat suku bunga acuan tidak memberikan pengaruh terhadap hasil investasi asuransi jiwa syariah di Indonesia dengan slope negatif pada koefesiennya

4. Nilai probabilitas indeks harga saham gabungan sebesar 0,0023 lebih kecil dari 0,05 maka dapat disimpulkan bahwa Indeks Harga Saham Gabungan memberikan pengaruh terhadap hasil investasi asuransi jiwa syariah di Indonesia dengan slope negatif pada koefesiennya

\section{Uji Signifikansi Simultan (Uji F)}

Uji ini dilakukan untuk mengetahui apakah terdapat pengaruh semua variabel bebas terhadap variabel terikat yaitu investasi asuransi jiwa syariah di Indonesia. Melihat nilai prob (F-statistic) pada tabel 4 sebesar 0,000002 lebih kecil dari 0,05 maka dapat disimpulkan bahwa terdapat pengaruh secara bersama - sama dari variabel bebas yaitu Inflasi, Kurs, Suku Bunga Acuan, dan IHSG terhadap hasil investasi asuransi jiwa syariah di Indonesia. Sehingga, keempat variabel di atas merupakan indikator ekonomi makro yang memiliki peran sangat penting dalam menentukan besar kecilnya hasil investasi yang dilaksanakan oleh asuransi jiwa syariah di Indonesia.

\section{Uji R - Square}

Uji ini digunakan untuk mengetahui sampai berapa besar persentase variasi dalam variabel terikat pada model dapat diterangkan oleh variabel bebasnya. Nilai $R^{2}$ berkisar antara $0<R^{2}<1$. Semakin besar $R^{2}$ maka persentase perubahan variabel terikat yang disebabkan variabel bebas semakin tinggi dan semakin kecil $\mathrm{R}^{2}$, maka persentase perubahan variabel terikat yang disebabkan oleh variabel bebas semakin rendah. Dengan melihat hasi output dapat diketahui bahwa nilai Adjusted R-Squared adalah 0,994143. Hal ini menunjukkan bahwa hasil investasi syariah dapat dijelaskan oleh variabel inflasi, kurs, suku bunga acuan, dan IHSG sebesar 99,41\% sedangkan sisanya sebesar 0,59\% dijelaskan oleh faktor lain yang tidak termasuk dalam penelitian 
ini.

Selanjutnya adalah mengetahui pengaruh variabel bebas terhadap variabel terikat dilakukan dengan menggunakan model regresi berganda. Hasil perhitungan regresi ganda dengan menggunakan program Eviews 10 dapat dilihat seperti berikut:

\section{INV $=-23.5278-0.1821 * I N F+2.1949 *$ KURS $-0.1062 *$ SBA $+1.3752 *$ IHSG}

1. Pada persamaan di atas, nilai koefesien $\beta_{0}=$ konstanta $=-23,52782$, hal ini mempunyai makna bahwa apabila inflasi, kurs, suku bunga acuan dan IHSg = 0 atau ditiadakan maka tidak akan ada investasi asuransi jiwa syariah di Indonesia dengan tingkat keyakinan $95 \%$.

2. $\beta_{1}$ merupakan nilai koefesien dari variabel inflasi dengan besaran $-0,1821$ yang berarti jika inflasi meningkat sebesar satu maka investasi asuransi jiwa syariah di Indonesia akan turun sebesar 0,1821 persen. Sebaliknya apabila inflasi turun sebesar satu maka investasi akan naik sebesar 0,1821 persen dengan asumsi variabel yang lain tetap. Inflasi yang memberikan pengaruh positif sesuai dengan teori yang dikemukakan Asfia (2009;205) yang menyatakan inflasi menyebabkan investasi produktif berkurang dan kegiatan ekonomi menurun. Inflasi juga mengakibatkan investor berusaha menyelamatkan perusahaan mereka dari kerugian. Dengan kata lain, inflasi berhubungan negatif dengan investasi (Mankiw, 2007)

3. $\beta_{2}$ merupakan nilai koefesien dari variabel kurs dengan besaran 2,194935 yang berarti jika kurs naik sebesar 1 maka hasil investasi asuransi jiwa syariah akan naik sebesar 2,194935 persen dengan asumsi variabel yang lain tetap. Hal ini dengan sejalan dengan penelitian yang dilakukan Meita dan Baskara (2018) yang menunjukkan bahwa nilai tukar (kurs) berpengaruh positif terhadap investasi langsung di Indonesia.

4. $\quad \beta_{3}$ merupakan nilai koefesien dari variabel suku bunga acuan dengan besaran nilainya -0,106160 yang berarti jika suku bunga acuan naik sebesar 1 maka hasil investasi asuransi jiwa syariah akan turun sebesar 0,106160 persen dengan asumsi variabel yang lain tetap. Namun, variabel ini tidak menyumbangkan pengaruh yang signifikan terhadap jumlah investasi asuransi jiwa syariah di Indonesia dikarenakan probabilitas dari suku bunga acuan lebih besar dari taraf signifikansi $5 \%(0,5372>0,05)$. Hasil ini sesuai dengan penelitian yang dilakukan Meita Sari dan Baskara (2018) dalam penelitiannya menunjukkan suku bunga berpengaruh negatif terhadap investasi asing langsung di Indonesia.

5. $\beta_{5}$ merupakan nilai koefesien dari variabel IHSG dengan besaran 1,375178 yang berarti jika IHSG naik sebesar 1 maka hasil investasi asuransi jiwa syariah juga akan naik sebesar 1,375178 persen dengan asumsi variabel yang lain tetap. Hal ini sesuai dengan penelitian yang dilakukan oleh Nidar dan Diwangsa (2017) bahwa 
pergerakan IHSG (Dow Jones) memberikan pengaruh yang positif terhadap keputusan investor.

\section{SIMPULAN}

Setelah melihat hasil analisis data yang telah diuji sebelumnya maka secara umum kondisi perekonomian makro dalam penelitian ini seperti Inflasi, Kurs, Suku Bunga Acuan dan IHSG memberikan pengaruh terhadap hasil investasi asuransi jiwa syariah di Indonesia dengan nilai prob (F-statistic) 0,000002 < 0,05 yang menunjukkan keempat variabel bebas memiliki pengaruh terhadap variabel terikat. Dalam uji yang dilakukan diketahui bahwa nilai uji t suku bunga acuan 0,53>0,05 menunjukkan bahwa variabel ini tidak memberikan pengaruh terhadap hasil investasi. Hal ini dikarenakan dalam asuransi jiwa syariah, dana yang dikelola tidak dikenakan bunga. Inflasi, kurs dan IHSG menunjukkan uji t < 0,05, ini menandakan bahwa ketiga variabel bebas ini mempengaruhi investasi asuransi jiwa syariah di Indonesia. Nilai Adjusted R-Squared 0,9941 telah menunjukkan bahwa 99,41\% variabel bebas mempengaruhi variabel terikat. Sehingga, pemerintah dipandang perlu untuk mengawasi dan menjaga kestabilan ekonomi agar tidak terjadi lonjakan harga - harga kebutuhan pokok yang mengakibatkan turunnya investor di pasar modal. Selanjutnya, perusahaan yang banyak memiliki investor asing di dalamnya harus selalu memantau nilai tukar mata uang asing karena apabila nilai tukar menurun tentunya akan berdampak terhadap hasil investasi. Untuk pengembangan penelitian selanjutnya bisa memasukkan variabel ekonomi lainnya seperti tingkat hutang luar negeri Indonesia, tingkat pajak yang berlaku dan GDP per kapita. Objek penelitian juga dapat diganti dengan hasil investasi perusahaan asuransi umum syariah dan reasuransi syariah. Keduanya merupakan lembaga keuangan syariah yang mempunyai potensi untuk ikut meningkatkan perekonomian Indonesia dan mendukung gerakan ekonomi syariah yang sedang tren di Indonesia. 


\section{PUSTAKA ACUAN}

Karim, Adiwarman. (2014). Ekonomi Makro Islami. Jakarta : PT. Raja Grafindo Persada

Alhasymi, M. 2010. Pengaruh Inflasi, Suku Bunga Riil dan Kurs terhadap Investasi Asing Langsung di Indonesia. Yogyakarta : YKPN

Anshory, Abdul Ghafur. 2007. Asuransi Syariah di Indonesia : Regulasi dan Operasionalisasinya di dalam Kerangka Hukum Positif di Indonesia. Yogyakarta : UII Press

Badan Pusat Statistik. 2019. Pendapatan Nasional Indonesia 2014-2018

Bank Indonesia. 2020. Perkembangan Inflasi dan Nilai Tukar di Indonesia

Bursa Efek Indonesia. 2020. Perkembangan Indeks Harga Saham Gabungan.

Chen, Roll dan Ross. 2004. The Determinants of Financial Health of Asian Insurance Companies. Journal of Risk and Insurance, $71: 469$ - 499

Huda, Nurul \& Risza Idris, Handi, dkk. (2008). Ekonomi Makro Islami. Jakarta : Kencana

Irmawati, Dewi. 2017. Pengaruh Tingkat Suku Bunga (Bi Rate), Tingkat Inflasi dan Nilai Tukar Rupiah terhadap Hasil Investasi Perusahaan Asuransi Jiwa Syariah di Indonesia Periode 2014-2016. Repository IAIN - Tulungagung

Keputusan Menteri Agama RI Nomor 336 tahun 2018 tentang Penyelenggaraan Haji dan Umrah

Mankiw, Gregory N. (2007). Makroekonomi. Jakarta : PT. Erlanggga

Meita, Sari \& Baskara, Kajeng. (2018). Pengaruh Pertumbuhan Ekonomi, Suku Bunga, dan Nilai Tukar terhadap Investasi Asing Langsung di Indonesia. E-Jurnal Manajemen Unud, Vol. 7, No. 7 : 4002-4030

Nachrowi, D \& Usman, Hardius. (2006). Pendekatan Populer dan Praktis Ekonometrika untuk Analisis Ekonomi dan Keuangan. Jakarta : Fakultas Ekonomi Universitas Indonesia

Nidar, Sulaeman \& Diwangsa, Erwin. (2017). The Influence of Global Stock Index and the Economic Indicators of Stock Investment Decision by Foreign Investors in the Indonesian Stock Exchange. J. Fin. Bank. Review 2 (1) $32-37$ (2017)

Otoritas Jasa Keuangan. 2020. Investasi Terbesar yang Menjadi Pilihan Perusahaan Asuransi Jiwa Syariah

Pasaribu, R. B., \& Kowanda, D. 2014. Pengaruh Suku Bunga SBI, Tingkat Inflasi, IHSG, dan Burs Asing Terhadap Tingkat Pengembalian Reksadana Saham. Jurnal Akuntansi \& Manajemen : JAM, 53-65

Republik Indonesia. Peraturan Menteri Keuangan Nomor 11/pmk.010/2011 tentang Kesehatan Keuangan Usaha Asuransi dan Usaha Reasuransi dengan Prinsip Syariah

Restiana, UU. 2017. Pengaruh Fluktuasi IHSG, Tingkat Inflasi, Dan Bi 7-Days Repo 
Rate Terhadap Return Unitlink Syariah Berbasis Saham Di Indonesia Tahun 2017. eprints.iain-surakarta.ac.id.

Sukirno, Sadono. (2004) Makroekonomi Teori Pengantar. Jakarta : Rajawali Pers

Zein, FD \& Shofawati, Atina. (2017). Kondisi Ekonomi Makro Ekonomi terhadap Hasil Investasi Jiwa Syariah di Indonesia. Jurnal Ekonomi Syariah dan Terapan, 10(4), 773-786 